\title{
A simple and high-yield synthesis of (S)-BZM, (R)-BZM and (S)-IBZM for the preparation of (S)-123I-IBZM
}

\section{Citation for published version (APA):}

Bobeldijk, M., Verhoeff, N. P. L. G., Vekemans, J. A. J. M., Buck, H. M., van Doremalen, P. A. P. M., Hoof, van, J. J., \& Janssen, A. G. M. (1990). A simple and high-yield synthesis of (S)-BZM, (R)-BZM and (S)-IBZM for the preparation of (S)-123I-IBZM. Journal of Labelled Compounds and Radiopharmaceuticals, 28(11), 1247-1256. https://doi.org/10.1002/jlcr.2580281104

DOI:

10.1002/jlcr.2580281104

Document status and date:

Published: 01/01/1990

\section{Document Version:}

Publisher's PDF, also known as Version of Record (includes final page, issue and volume numbers)

\section{Please check the document version of this publication:}

- A submitted manuscript is the version of the article upon submission and before peer-review. There can be important differences between the submitted version and the official published version of record. People interested in the research are advised to contact the author for the final version of the publication, or visit the $\mathrm{DOI}$ to the publisher's website.

- The final author version and the galley proof are versions of the publication after peer review.

- The final published version features the final layout of the paper including the volume, issue and page numbers.

Link to publication

\section{General rights}

Copyright and moral rights for the publications made accessible in the public portal are retained by the authors and/or other copyright owners and it is a condition of accessing publications that users recognise and abide by the legal requirements associated with these rights.

- Users may download and print one copy of any publication from the public portal for the purpose of private study or research.

- You may not further distribute the material or use it for any profit-making activity or commercial gain

- You may freely distribute the URL identifying the publication in the public portal.

If the publication is distributed under the terms of Article 25fa of the Dutch Copyright Act, indicated by the "Taverne" license above, please follow below link for the End User Agreement:

www.tue.nl/taverne

Take down policy

If you believe that this document breaches copyright please contact us at:

openaccess@tue.nl

providing details and we will investigate your claim. 


\section{A SIMPLE AND HIGH-YIELD SYNTHESIS OF (S)-BZM, (R)-BZM}

\section{AND (S)-IBZM FOR THE PREPARATION OF (S) $-{ }^{123}$ I-IBZM}

M. Bobeldijk ${ }^{*+o}$, N.P.L.G. Verhoeff*, J.A.J.M. Vekemans';

H.M. BuCk*, P.A.P.M. van Doremalen ${ }^{+\infty}$, J.J. van Hoof ${ }^{+\infty}$ and

A.G.M. Janssen ${ }^{+0 x}$.

\# : Department of Organic Chemistry, Eindhoven

University of Technology, The Netherlands,

* : Department of Nuclear Medicine, Academic Medical

Centre, Amsterdam, The Nether 7 ands,

+ : Cygne B.V., Eindhoven, The Netherlands and

0 : Faculty of Physics, Eindhoven University of

Technology, The Nether 7 ands.

$x$ : To whom correspondence should be adressed: Faculty of

Physics, Eindhoven University of Technology,

Cyclotron Building 1.11, P.0. Box 513,

5600 MB Eindhoven, The Netherlands.

\section{SUMMARY}

(S)-2-Hydroxy-6-methoxy-N-[(1-ethy]-2-pyrrol idiny] )methyl ]benzamide ((S)-BZM; (S)-5a ), the precursor of (S)-2-hydroxy-3-123I-iodo-6methoxy-N-[(1-ethy]-2-pyrrolidiny $]$ )methyl ]benzamide ((S)- $\left.{ }^{123} I-I B Z M\right)$ was synthesized via a simple method and in high yield starting from 2,6-dimethoxybenzoic acid (1a). N-Hydroxysuccinimide/dicyclohexylcarboditimide (DCC) was used as activating system in the reaction of 1a with (S)-2-aminomethyl-1-ethylpyrrolidine (aa).

Keywords: ${ }^{123} I$, Benzamides, Dopamine D-2 receptor imaging agent. 


\section{INTRODUCTION}

Recent $] y,(S)-2-h y d r o x y-3-{ }^{123} I-i o d o-6-m e t h o x y-N-[(1-e t h y]-2-p y r r o 1$ idiny 1$)$ methyl Jbenzamide ( $(S)-{ }^{123}$ I-IBZM, Figure 1) has been introduced as a promising radio-1 igand for in-vivo CNS dopamine D-2 receptor imaging. ${ }^{1-6}$

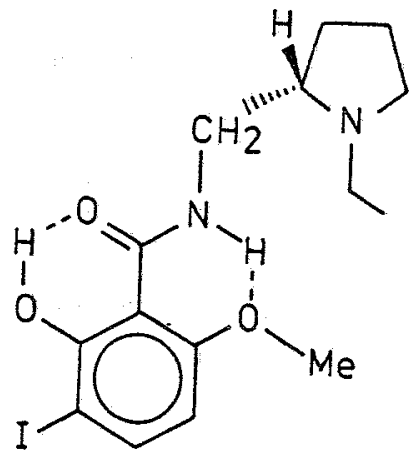

Figure 1. (S)-2-hydroxy-3-123I-jodo-6-methoxy-N-[(1-ethy]-2-pyrrolidinyl)methyl ]benzamide $\left((S)-{ }^{123} I-I B Z M\right)$

A synthetic route to a series of substituted benzamides has been described by de Paulis et al. ${ }^{7,8} A$ synthesis of IBZM and BZM, basically via the same route, has been published by kung et al.9

Our goal was to develop a simple synthes is of both $(S)-B Z M((S)-\underline{5 a})$, the precursor of $(S)-{ }^{123} I-I B Z M$, and $(R)-B Z M((R)-\underline{5 a})$. The preparation of benzamides as described by de Paul is et a1., ${ }^{7,8}$ and the synthes is of BZM by Kung et al. ${ }^{9}$ via acid chlorides appears less attractive because of the relatively low yields (15-50\%, and 55\% respectively), and the instability of the intermediate acid chlorides. Instead of activating 2,6-dimethoxybenzoic acid (1a) with thionyl chloride, the potency of $\mathrm{N}$-hydroxysuccinimide/DCC in this respect was investigated.

Due to the low concentration of dopamine $D-2$ receptors present in brain tissue, a high specific activity is mandatory. Since this is not attainable by isotopic exchange labeling, direct oxidative iodination of (S)-BZM was 
pursued. For the removal of the uniodinated substrate an alternative for the time consuming, preparative HPLC procedure was developed.

\section{RESULTS AND DISCUSSION}

Synthesis of (S)-BZM, (R)-BZM and (S)-IBZM

(S)-BZM was synthesized from its corresponding benzoic acid (1a) with the aid of $\mathrm{N}$-hydroxysucc in imide ${ }^{10}$ (Scheme $\mathrm{I}$ ), which has been succesfully applied in peptide synthes is." The resulting succinimate ester (2a) may be coupled with a primary amine of choice and represents a stable, well characterizable, common precursor for both (S)-BZM and (R)-BZM. The reaction of succinimate esters with an appropriate chiral amine is known to proceed in high yield and without racemization. ${ }^{10,11}$

Apart from the synthet ic advantage of a common precursor, the overall yield following this procedure is signifantly higher: (S)-BZM and (R)-BZM were synthesized in an overall yield of approx. $70 \%$, which compares favourably with the value of $26 \%$ reported by de Paul is et $21 .{ }^{\prime}$ and of $55 \%$ reported by Kung et a1.' (S)-IBZM was prepared starting from 2,6-dimethoxy-3-iodobenzoic acid ( $\underline{1 b})$, following an analogous reaction sequence (Scheme I). It was used for identification purposes.

\section{Radiol abeling}

The radiolabeling procedure applied is essentially the same as described by Kung et $21 . .^{12}$ Instead of using peracetic acid we generated this oxidant in-situ from acetic acid/ hydrogen peroxide added to the reaction mixture. The radiolabeling of $(S)$-BZM to $(S)^{-123} I-I B Z M$, proceeded with a yield of $80-85 \%$, which is slightly lower than the reported $95 \%$ by Kung et $21 .{ }^{12}$ The overall radiochemical yield amounts to $60-65 \%$, mainly due to losses in the purification steps. The specific activity of ${ }^{123} \mathrm{I}-\mathrm{IBZM}$ obtained, amounts to $\geq 3000 \mathrm{Ci} / \mathrm{mmol}(\geq 100 \mathrm{TBq} / \mathrm{mmol})$.

A distinct feature of the procedure is the use of a disposable C-18 cartridge instead of a time-consuming, preparative HPLC separation. Thus, 


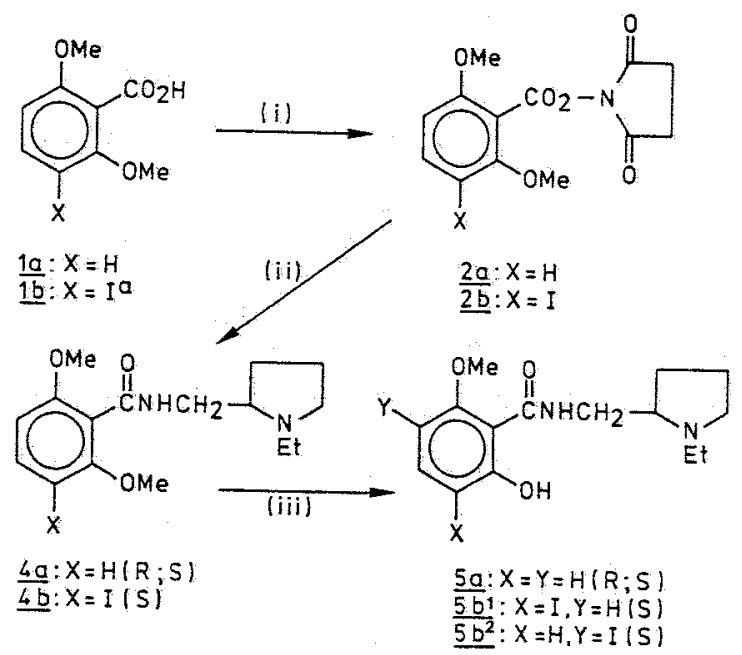

Scheme $I$. The synthesis of $(S)-B Z M,(R)-B Z M$ and $(S)-I B Z M$

(i): N-hydroxysuccinimide/DCC in 1,4-dioxane, (ii): 2-aminomethy 7 -1ethylpyrrolidine in $\mathrm{CH}_{2} \mathrm{Cl}_{2}$, (iii): $\mathrm{BBr}_{3}$ in $\mathrm{CH}_{2} \mathrm{Cl}_{2}$, (a): 1a was transformed into $1 \mathrm{~b}$ in three steps: (1): $\mathrm{HNO}_{3}$ in $\mathrm{H}_{2} \mathrm{SO}_{4} ;(2): \mathrm{H}_{2}, \mathrm{Pd} / \mathrm{C}, \mathrm{HCl}$ in $\mathrm{EtOH} ;(3): \mathrm{NaNO}_{2}, \mathrm{KI}$ in $\mathrm{H}_{2} \mathrm{SO}_{4}$.

drawbacks of preparative HPLC such as the recovery of the product from a relative large volume of solvent, high-level radioactive contamination of the system, and the interference with aseptic preparation are avoided, and HPLC is only used for analys is.

In-vitro saturation and displacement studies and in-vivo binding studies, with (S)- ${ }^{123} I-I B Z M,(S)-B Z M$ and (R)-BZM will be published in a separate article. ${ }^{13}$

\section{EXPERIMENTAL}

${ }^{2} H$ NMR spectra were recorded on a Bruker AC 200 spectrometer in $\mathrm{CDCl}_{3}$ with TMS as internal standard. $[\alpha]_{0}^{20}$ Values were measured on an Optical Activity A-10 polarimeter. HPLC analys is was performed on a waters system, equipped with a model 510 pump, U6k injector, RP-Cl8 column and 
Lambda-Max-481 UV-absorbance detector. ${ }^{123}$ I-NaI Was provided by Cygne B.V., Eindhoven, The Netherlands.

Synthes is of (S)-BZM, (R)-BZM and (S)-IBZM

2,6-Dimethoxy-3-iodo-benzoic acid (1b). - 2,6-Dimethoxy-3-iodo-benzoic acid (1b) was prepared from 2,6-dimethoxybenzoic acid (1a) according to methods in the literature ${ }^{14,15}$ (Scheme I). The iodination, however, was performed on the HCl-salt of 3-amino-2,6-dimethoxybenzoic acid.

\section{Succinimate ester of 2,6-dimethoxybenzoic acid (2a). ${ }^{10}$}

$1 \mathrm{a}(5.47 \mathrm{~g}, 30 \mathrm{mmol})$ and $\mathrm{N}$-hydroxysuccinimide $(4.32 \mathrm{~g}, 37.5 \mathrm{mmol})$ were dissolved in dry 1,4 -dioxane $(45 \mathrm{ml})$. To this solution dicyclohexylcarbodi imide $(9.20 \mathrm{~g}, 45 \mathrm{mmol})$ was added. A little rise of temperature was noted and after approx. five minutes a white solid (dicyclohexylurea) precipitated. The reaction mixture was stirred overnight, the insoluble material was filtered off and washed with dry 1,4-dioxane. The combined filtrates were evaporated to leave a solid residue which was triturated with dry diethyl ether. Crystallization from EtOAc gave $\underline{\mathbf{2 a}}$. Yield: $7.25 \mathrm{~g}=87 \%$; $\mathrm{mp}$ : $201-202^{\circ} \mathrm{C} ;{ }^{3} \mathrm{H}$ NMR: $\delta: 7.40\left(\mathrm{t}, J=8.4 \mathrm{~Hz}, 1 \mathrm{H}, \mathrm{H}_{4}\right) ; 6.60(\mathrm{~d}, J=8.6 \mathrm{~Hz}, 2 \mathrm{H}$, $\left.\mathrm{H}_{3}+\mathrm{H}_{5}\right) ; 3.89(\mathrm{~s}, 6 \mathrm{H}, \mathrm{OMe}) ; 2.88\left(\mathrm{~s}, 4 \mathrm{H}, \mathrm{CH}_{2}\right)$.

Succinimate ester of 2,6-dimethoxy-3-iodo-benzoic acid (2b)..$^{10}$

$\underline{2 b}$ was prepared in the same manner starting from $\underline{1 b}$. Crystallization from EtOAc:petroleum ether $(1: 1)$. Yield: $92 \%$; mp: $126-127^{\circ} \mathrm{C} ;{ }^{\mathrm{I}} \mathrm{H}$ NMR: $6: 7.84$ (d, $\left.J=8.8 \mathrm{~Hz}, 1 \mathrm{H}, \mathrm{H}_{4}\right) ; 6.58\left(\mathrm{~d}, J=8.8 \mathrm{~Hz}, 1 \mathrm{H}, \mathrm{H}_{5}\right) ; 3.97(\mathrm{~s}, 3 \mathrm{H}, 2-0 \mathrm{Me}) ; 3.89$ $(\mathrm{s}, 3 \mathrm{H}, 6-\mathrm{OMe}) ; 2.90\left(\mathrm{~s}, 4 \mathrm{H}, \mathrm{CH}_{2}\right)$.

\section{(S)-2,6-Dimethoxy-N-[(1-ethy $]-2-$ pyrro] id iny $])$ methy $]$ benzamide $((S)-4 a) . .^{\text {to }}$}

To a solution of $\underline{2 a}(5.60 \mathrm{~g}, 20 \mathrm{mmol})$ in $\mathrm{CH}_{2} \mathrm{Cl}_{2}$ (30 $\left.\mathrm{ml}\right)(\mathrm{S})$-2-aminomethyl-1ethylpyrrolidine $(\underline{3 a} ; 2.69 \mathrm{~g}, 21 \mathrm{mmol})$ was added dropwise. A little rise of temperature was noted. After two hours of stirring, iN $\mathrm{NaOH}(40 \mathrm{ml})$ was added and the mixture was stirred for an additional hour. The layers were 
separated and the aqueous layer was extracted with $\mathrm{CH}_{2} \mathrm{Cl}_{2}(3 \times 50 \mathrm{~m} 1)$. The combined organic layer was dried $\left(\mathrm{MgSO}_{4}\right)$ and the solvent was evaporated. Crystallization from diisopropyl ether gave $(S)$-4a . Yield: $5.56 \mathrm{~g}=95 \%$; mp: $114^{\circ} \mathrm{C}\left(7 \mathrm{it}^{7}: 100-102^{\circ} \mathrm{C}\right)$; ${ }^{\mathrm{H}} \mathrm{NMR}: \delta: 7.26\left(\mathrm{t}, \mathrm{J}=8.4 \mathrm{~Hz}, 1 \mathrm{H}, \mathrm{H}_{4}\right) ; 6.56$ (d, $\left.J=8.4 \mathrm{~Hz}, 2 \mathrm{H}, \mathrm{H}_{3}+\mathrm{H}_{5}\right) ; 6.28$ (bs, IH, NH); $3.8 \mathrm{I}(\mathrm{s}, 6 \mathrm{H}, \mathrm{OMe}) ; 3.0-3.4$ $(\mathrm{m}, 2 \mathrm{H}) ; 2.85\left(\mathrm{dd}, J_{1}=8.0 \mathrm{~Hz}, J_{2}=7.5 \mathrm{~Hz}, I \mathrm{H}\right) ; 2.5-2.7(\mathrm{~m}, 1 \mathrm{H}) ; 2.0-2.3$ $(\mathrm{m}, 3 \mathrm{H}) ; 1.5-2.0(\mathrm{~m}, 4 \mathrm{H}) ; 1.07\left(\mathrm{t}, J=7.2 \mathrm{~Hz}, 3 \mathrm{H}, \mathrm{N}-\mathrm{CH}_{2}-\mathrm{CH}_{3}\right) ;[\alpha]_{0}^{20}:-58.8^{\circ}$ (c = 2, acetone; $\left.1 \mathrm{it}^{7}:-59^{\circ}\right)$.

(R) -2,6-Dimethoxy-N-[(1-ethy]-2-pyrrol id inyl )methy $]]$ benzamide $((R)-4 a) .^{10}$ (R)-4a was prepared in the same manner with (R)-2-aminomethyl-1-ethylpyrrolidine ( $\underline{3 b})$. Yie]d $94 \%$; mp: $114^{\circ} \mathrm{C} ;[\alpha]_{0}^{20}:+59.3^{\circ}(\mathrm{c}=2$, acetone).

(S) -2,6-Dimethoxy-3-iodo-N-[(1-ethy]-2-pyrrol id iny 1$)$ methyl $]$ benzamide (4b).$^{10}$ 4b Was prepared in the same manner from $\underline{2 b}$. Crystallization from dijsopropyl ether. Yield 96\%; mp: $112^{\circ} \mathrm{C}\left(1 \mathrm{it}^{7}: 112-113^{\circ} \mathrm{C}\right)$; ${ }^{\mathrm{i}} \mathrm{H}$ NMR: $\delta: 7.70(\mathrm{~d}, \mathrm{~J}=$ $\left.8.8 \mathrm{~Hz}, 1 \mathrm{H}, \mathrm{H}_{4}\right) ; 6.52\left(\mathrm{~d}, J=8.8 \mathrm{~Hz}, 1 \mathrm{H}, \mathrm{H}_{5}\right) ; 6.31$ (bs, $\left.1 \mathrm{H}, \mathrm{NH}\right) ; 3.87$ ( $\mathrm{s}$, $3 \mathrm{H}, 2-\mathrm{OMe}) ; 3.81(\mathrm{~s}, 3 \mathrm{H}, 6-\mathrm{OMe}) ; 3.0-3.4(\mathrm{~m}, 2 \mathrm{H}) ; 2.83\left(\mathrm{dd}, \mathrm{J}_{1}=7.4 \mathrm{~Hz}, \mathrm{~J}_{2}=\right.$ $12.1 \mathrm{~Hz}, 1 \mathrm{H}) ; 2.5-2.8(\mathrm{~m}, 1 \mathrm{H}) ; 1.5-2.4(\mathrm{~m}, 7 \mathrm{H}) ; 1.07(\mathrm{t}, J=7.2 \mathrm{~Hz}, 3 \mathrm{H}$, $\left.\mathrm{N}-\mathrm{CH}_{2}-\mathrm{CH}_{3}\right) ;[\alpha]_{0}^{20}:-66.8^{\circ}\left(\mathrm{C}=2\right.$, acetone; $\left.1 i \mathrm{t}^{3}:-67^{\circ}\right)$.

Resolution of the isomeric pyrrolidines. ${ }^{16}$-. (S)-2-amino-methyl-1-ethylpyrrolidine ( $\underline{3 \mathrm{a}})$ : Yield: $48 \% ;[\alpha]_{0}^{20}:-54.7^{\mathrm{a}}\left(\mathrm{c}=1, \mathrm{CHCl}_{3}\right) ;(\mathrm{R})-2$-aminomethyl-1-ethylpyrrolidine ( $\underline{\mathbf{3 b}})$ : Yield: $47 \% ;[\alpha]_{0}^{20}:+55.1^{\circ}\left(\mathrm{c}=1, \mathrm{CHCl}_{3}\right)$. ${ }^{2} \mathrm{H}$ NMR of racemic 2-aminomethyl-1-ethylpyrrolidine: $\delta: 3.16$ (qui, $J=4.8$ $\mathrm{Hz}, 1 \mathrm{H}) ; 2.7-2.9(\mathrm{~m}, 3 \mathrm{H}) ; 2.35(\mathrm{~m}, 1 \mathrm{H}) 2.1-2.3(\mathrm{~m}, 2 \mathrm{H}) ; 1.6-1.9(\mathrm{~m}, 4 \mathrm{H})$; $1.3-1.5(\mathrm{~m}, 2 \mathrm{H}) ; 1.10\left(\mathrm{t}, \mathrm{J}=7.2 \mathrm{~Hz}, 3 \mathrm{H}, \mathrm{N}-\mathrm{CH}_{2}-\mathrm{CH}_{3}\right)$.

(S) -2-Hydroxy-6-methoxy-N-[(1-ethy]-2-pyrrolid iny 1$)$ methy $]]$ benzamide, $((S)-B Z M ;(S)-5 a)) .^{7}$ - A stirred solution of $(S)-\underline{4 a}(3.0 \mathrm{~g}, 10.2 \mathrm{mmol})$ in $\mathrm{CH}_{2} \mathrm{Cl}_{2}(75 \mathrm{ml})$ was treated with $4 \mathrm{~N} \mathrm{HCl}$ in diethyl ether $(3.2 \mathrm{ml})$. Subsequently a solution of $\mathrm{BBr}_{3}(2.6 \mathrm{~g}, 10.2 \mathrm{mmol})$ in $\mathrm{CH}_{2} \mathrm{Cl}_{2}(17.5 \mathrm{ml})$ was added 
dropwise. After one hour IN ammonia $(25 \mathrm{ml})$ was added and stirring was continued for an additional hour. The layers were separated and the aqueous layer was extracted with $\mathrm{CH}_{2} \mathrm{Cl}_{2}(2 \times 50 \mathrm{ml})$. The combined organic layer was washed with water, dried $\left(\mathrm{Na}_{2} \mathrm{SO}_{4}\right)$ and concentrated. The residue was dissolved in dry diethyl ether and the insoluble material was removed by filtration. Finally the filtrate was evaporated to give (S)- $\underline{\mathbf{a}}$. Yield: $2.41 \mathrm{~g}=$ $85 \%$; ${ }^{\mathrm{H}} \mathrm{H}$ NMR: $\delta: 14.2(\mathrm{~s}, 1 \mathrm{H}, \mathrm{OH}) ; 8.93$ (bs, $\left.1 \mathrm{H}, \mathrm{NH}\right) ; 7.25(\mathrm{t}, J=8.3 \mathrm{~Hz}$, $\left.1 \mathrm{H}, \mathrm{H}_{4}\right) ; 6.61\left(\mathrm{dd}, J_{\text {orthe }}=8.3 \mathrm{~Hz}, J_{\text {mata }}=0.9 \mathrm{~Hz}, 1 \mathrm{H}, \mathrm{H}_{3}\right) ; 6.39\left(\mathrm{dd}, J_{\text {ortha }}=\right.$ $\left.8.3 \mathrm{~Hz}, J_{\text {meta }}=0.8 \mathrm{~Hz}, 1 \mathrm{H}, \mathrm{H}_{5}\right) ; 3.92(\mathrm{~s}, 3 \mathrm{H}, \mathrm{OMe}) ; 3.68(\mathrm{~m}, \mathrm{IH}) ; 3.1-3.4(\mathrm{~m}$, $2 \mathrm{H}) ; 2.7-3.0(\mathrm{~m}, 1 \mathrm{H}) ; 2.5-2.7(\mathrm{~m}, 1 \mathrm{H}) ; 2.1-2.4(\mathrm{~m}, 2 \mathrm{H}) ; 1.5-2.0(\mathrm{~m}, 4 \mathrm{H})$; $1.13\left(\mathrm{t}, \mathrm{J}=7.2 \mathrm{~Hz}, \mathrm{~N}-\mathrm{CH}_{2}-\mathrm{CH}_{3}\right) ;[\alpha]_{0}{ }^{20}:-55.7^{\alpha}$ ( $\mathrm{C}=2$, acetone; $\left.1 \mathrm{it}^{7}:-56^{\circ}\right)$. To a solution of $(S)$ - $\underline{5 a}$ in diethyl ether $(15 \mathrm{ml}), 4 \mathrm{~N} \mathrm{HCl}$ in diethyl ether $(3.0 \mathrm{ml})$ was added with stirring to precipitate $(S)-\underline{5 a} \cdot \mathrm{HCl}$. The solvent was decanted and the sticky solid was dried in vacuo at $50^{\circ} \mathrm{C}$. Overall yield: $2.41 \mathrm{~g}=75 \%$; mpt: $139^{\circ} \mathrm{C} ;{ }^{1} \mathrm{H}$ NMR: $\delta: 13.6$ (bs, $1 \mathrm{H}, \mathrm{OH}$ ); 12.2 (bs, $1 \mathrm{H}$, pyrr-

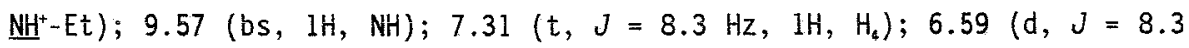
$\left.\mathrm{Hz}, 1 \mathrm{H}, \mathrm{H}_{3}\right) ; 6.44\left(\mathrm{~d}, J=8.3 \mathrm{~Hz}, 1 \mathrm{H}, \mathrm{H}_{5}\right) ; 4.12(\mathrm{~s}, 3 \mathrm{H}, \mathrm{OMe}) ; 3.7-4.1(\mathrm{~m}$, $4 \mathrm{H}) ; 3.1-3.4(\mathrm{~m}, 1 \mathrm{H}) ; 2.8-3.1(\mathrm{~m}, 2 \mathrm{H}) ; 1.8-2.4(\mathrm{~m}, 4 \mathrm{H}) ; 1.13(\mathrm{t}, J=7.2$ $\mathrm{Hz}, 3 \mathrm{H}$, pyrr $\left.-\mathrm{NH}^{+}-\mathrm{CH}_{2}-\mathrm{CH}_{3}\right)$.

(R) -2-Hydroxy-6-methoxy-N-[(1-ethy 1 -2-pyrro] id iny $])$ methyl]benzamide, $((R)-B Z M ;(R)-5 a)) .^{7}-(R)-B Z M$ was prepared in the same manner from (R) -4a. Yield: $76 \% ;[\alpha]_{0}^{20}:+56.1^{\circ}(c=2$, acetone $)$.

(5)-2-hydroxy-3-iodo-6-methoxy-N-[(1-ethy]-2-pyrrolidinyl)methy 1$]-$ benzamide, ((S)-IBZM; 5b1). -- A stirred solution of $4 \mathrm{bb}(2.16 \mathrm{~g}, 5 \mathrm{mmol})$ in $\mathrm{CH}_{2} \mathrm{Cl}_{2}(50 \mathrm{ml})$ was treated with $4 \mathrm{~N} \mathrm{HCl}$ in diethyl ether $(1.5 \mathrm{ml})$. Subsequently a solution of $\mathrm{BBr}_{3}(1.45 \mathrm{~g}, 5.8 \mathrm{mmol})$ in $\mathrm{CH}_{2} \mathrm{Cl}_{2}(12.5 \mathrm{ml})$ was added dropwise. After one hour $1 \mathrm{~N}$ ammonia $(25 \mathrm{ml})$ was added and stirring was continued for an additional hour. The layers were separated and the aqueous layer was extracted with $\mathrm{CH}_{2} \mathrm{Cl}_{2}(2 \times 30 \mathrm{ml})$. The combined organic layer was washed with water, dried $\left(\mathrm{Na}_{2} \mathrm{SO}_{4}\right)$ and concentrated. The residue 
was dissolved in dry diethyl ether $(30 \mathrm{mi})$ and the insoluble material was removed by filtration. The filtrate was evaporated. Crude yield: $1.92 \mathrm{~g}=$ 92\%. Column chromatography (silica gel; diisopropyl ether:methanol:ammonia $(80: 19: 1 \mathrm{v} / \mathrm{v}))$ yielded $1.3 \mathrm{~g}=65 \% \underline{\mathrm{bb1}}:{ }^{1} \mathrm{H}$ NMR: $6: 15.20$ (bs, $\left.1 \mathrm{H}, \mathrm{OH}\right) ; 8.97$ (bs, $1 H, N H) ; 7.71$ (d, $\left.J=8.8 \mathrm{~Hz}, 1 \mathrm{H}, H_{4}\right) ; 6.27\left(\mathrm{~d}, J=8.8 \mathrm{~Hz}, 1 \mathrm{H}, H_{5}\right)$; $3.92(\mathrm{~s}, 3 \mathrm{H}, \mathrm{OMe}) ; 3.68(\mathrm{~m}, 1 \mathrm{H}) ; 3.1-3.4(\mathrm{~m}, 2 \mathrm{H}) ; 2.6-3.0(\mathrm{~m}, 2 \mathrm{H}) ; 2.1-2.4$ $(\mathrm{m}, 2 \mathrm{H}) ; 1.5-2.0(\mathrm{~m}, 4 \mathrm{H}) ; 1.13\left(\mathrm{t}, J=7.2 \mathrm{~Hz}, 3 \mathrm{H}, \mathrm{N}-\mathrm{CH}_{2}-\mathrm{CH}_{3}\right)$. Also $210 \mathrm{mg}$ $=10 \%(\mathrm{~S})-2-$ hydroxy -5 -iodo-6-methoxy-N-[(1-ethy $1-2-$ pyrrol id inyl)methy $]]-$ benzamide ( $\underline{5 \mathrm{~b} 2}$ ) was isolated: $\mathrm{H}$-NMR: $6: 14.65(1 \mathrm{H}, \mathrm{OH}) ; 8.96$ (bs, $1 \mathrm{H}, \mathrm{NH})$; $7.69\left(\mathrm{~d}, J=8.8 \mathrm{~Hz}, 1 \mathrm{H}, \mathrm{H}_{3}\right) ; 6.26\left(\mathrm{~d}, J=8.8 \mathrm{~Hz}, 1 \mathrm{H}, \mathrm{H}_{4}\right) ; 3.92(\mathrm{~s}, 3 \mathrm{H}$, $\mathrm{OMe}) ; 3.70(\mathrm{~m}, 1 \mathrm{H}) ; 3.1-3.4(\mathrm{~m}, 2 \mathrm{H}) ; 2.6-3.0(\mathrm{~m}, 2 \mathrm{H}) ; 2.1-2.4(\mathrm{~m}, 2 \mathrm{H})$; $1.5-2.0(\mathrm{~m}, 4 \mathrm{H}) ; 1.13\left(\mathrm{t}, \mathrm{J}=7.2 \mathrm{~Hz}, 3 \mathrm{H}, \mathrm{N}-\mathrm{CH}_{2}-\mathrm{CH}_{3}\right)$.

\section{Radiol abeling}

For the oxidative iodination of (S)-BZM, ${ }^{123} \mathrm{I}-\mathrm{NaI}$ (Specific activity: $\geq 3000$ $\mathrm{Ci} / \mathrm{mmol}\left(\geq 100 \mathrm{TBq} / \mathrm{mmol}^{2}\right.$; radionuclidic purity: $\left.\geq 99.99 \%\right)$, produced via the indirect proton reaction on $99.8 \%$ enriched ${ }^{124} \mathrm{Xe}$, was used. ${ }^{17}$ To a solution of $(\mathrm{S})-\mathrm{BZM} \cdot \mathrm{HCl}(0.13 \mu \mathrm{mol})$ in $\mathrm{EtOH}\left(\begin{array}{ll}20 & \mu 1\end{array}\right)$ were added consecutively: ammonium acetate buffer $(275 \mu] ; \mathrm{pH}=4), \mathrm{H}_{2} \mathrm{O}_{2}(30 \%): H O A C=2: 1 \mathrm{v} / \mathrm{v}(10 \mu 1)$ and a solution of ${ }^{123} \mathrm{I}$-iodide in $0.05 \mathrm{M} \mathrm{NaOH}(<100 \mu 1)$. After approx. 10 minutes at ambient temperature, unreacted ${ }^{123} \mathrm{I}$-iodide was removed by passing the solution over a weakly basic anion exchange resin [Sephadex DEAE-A25, Pharmacia]. The radiochemical yield amounted to $80-85 \%$. To remove unreacted BZM the reaction mixture was loaded on a $\mathrm{C}-18$ cartridge [Bond Elute, $1 \mathrm{~m} 7$, Analytech]. This column was washed subsequently with water (1 ml) and with a mixture of $0.5 \mathrm{M}$ ammonium acetate buffer $(\mathrm{pH}=9)$ : EtOH:water $(\mathrm{V} / \mathrm{V}=$ $7: 18: 24 ; 20-25 \mathrm{ml})$. The removal of (S)-BZM from the column was checked with HPLC (UV-detection: wavelength $=254 \mathrm{~nm}$ ). If necessary, this procedure was repeated. Final1y (S) $-{ }^{123} I-I B Z M$ was eluted from the cartridge with EtOH:HOAC $(v / v=200: 1 ; 2-5 \mathrm{~m} 1)$. The eluate was evaporated and the residue was dissolved in EtOH. HPLC-analys is demonstrated, that the specific activity 
had not changed during the radiolabeling procedure and still amounted to $\geq 3000 \mathrm{Ci} / \mathrm{mmol}(\geq 100 \mathrm{TBq})$. The overall radiochemical yield amounted to approx. 60-65\%. The product was formulated with isotonic phosphate buffer $(\mathrm{pH}=6)$ to a final solution containing $<10 \%(\mathrm{v} / \mathrm{v})$ EtOH at activity concentration $2 \mathrm{mCi} / \mathrm{ml}(75 \mathrm{MBq} / \mathrm{ml})$.

\section{CONCLUSIONS}

(S)-BZM, the precursor of (S) ${ }^{123} \mathrm{I}-\mathrm{IBZM}$, can be synthesized in high overall yield (69\%) using the method described. The standard way to convert the benzoic acids into their corresponding benzamides, via their acid chlorides suffers from two major disadvantages: the acid chlorides cannot be stored for longer periods and the yields are modest (approx 50\%). Conversion of the benzoic acids $\underline{1 a}$ and $\underline{1 b}$ into their corresponding benzamides $\underline{\mathbf{4 a}}$ and $\underline{\mathbf{4 b}}$ with the aid of $\mathrm{N}$-hydroxysuccinimide/DCC via their common stable succinimate precursor, results in higher yields $(80-90 \%)$. The prepared (S)-BZM provided a suitable substrate for oxidative iodination, leading to $(S){ }^{123} \mathrm{I}-\mathrm{IBZM}$.

\section{ACKNOWLEDGEMENT}

The authors wish to thank Prof.dr. J.J.M. de Goeij for his advise in preparing the manuscript.

\section{REFERENCES}

1 : Kung H.F.; Guo Y.Z.; Bi11 ings J.; Xu X.; Mach R.H.; BTau M.; Ackerhalt R.E.; Nucl.Med.Biol. 15: 195 (1988).

2 : Kung H.F.; Kung M.P.; Pan S.; Kasliwal R.; Billings J.; Guo Y.Z.; 7th Int. Symp. on Radiopharm. Chem., Groningen, The Netherlands, July $\overline{4}-\overline{8}, \overline{1988}, \bar{p} \overline{9} \overline{8}-\overline{9} 9$. 
3 : Kung H.F.; Billings J.; Guo Y.Z.; Mach R.H.; Nucl.Med.Bio7. 15: 203 (1988).

4 : Kung M.P.; Murphy R.A.; Billings J.; Reilly J.; Alavi A.; Kung H.F.; J.Nuc7.Med. 30: 762 (1989).

5 : Kung H.F.; Alavi A.; Kung M.P.; Pan S.; Billings J.; Kasliwal R.; Reilly J.; J.Nucl.Med. 29: 759 (1988).

6 : Kung H.F.; Pan S.; Kung M.P.; Bi1lings J.; Kasliwal R.; Reilly J.; Alavi A.; J.Nuc7.Med. 30: 88 (1989).

7 : Paul is T. de; Kumar Y.; Johansson L.; Rämsby S.; Florval1 L.;

Ha11 H.; Ängeby-Möller K.; Ögren S.; J.Med.Chem. 28: 1263 (1985).

8.: Paul is T. de; Kumar Y.; Johansson L.; Rämsby S.; Hall H.;

Sällemark M.; Ängeby-Möller K.; Ögren S.; J.Med.Chem. 292: 61 (1986).

9 : Kung H.F.; Kasliwal R.; Pan S.; Kung M.P.; Mach R.H.; Guo Y.Z.;

J.Med.Chem. 31: 1039 (1988).

10 : Brussel W. van; Sumere C.F. van; Bul7.Soc.Chim.Be7g. 87: 791 (1978).

11 : Schnaar R.L.; Lee Y.C.; Biochemistry 14: 1535 (1975).

12 : Kung M.P.; Kung H.F.; J.Lab.Comp.Radiopharm. 26: 691 (1989)

13 : Verhoeff N.P.L.G.; Bobeldijk M.; Royen E.A. van; Feenstra M.G.P.;

Boer G.J.; Doremalen P.A.P.M. van; Erdtsieck-Ernste E.;

submitted for publication.

14 : Brian E.G.; Doyle F.P.; Metha M.D.; Miller D.; Nayler J.H.C.;

Stove E.R.; J.Chem.Soc.: 491 (1963).

15 : Doyle F.P.; Nayler J.H.C.; Waddington H.R.J.; Hanson J.C.;

Thomas G.R.; J.Chem.Soc.: 497 (1963).

16 : BuTteau G.; French Patent 1528 014, 1968.

17 : Witsenboer A.J.; Goeij J.J.M. de; Reiffers S.; J.Lab.Comp.Radiopharm. 23: 1284 (1986). 